\title{
EXPLORING THE APPLICATION OF LEAN PRINCIPLES TO A CONSTRUCTION SUPPLY CHAIN
}

\author{
Rafaella Broft ${ }^{1}$
}

\begin{abstract}
The characteristics known in construction are often seen as peculiarities of the industry and prevent the attainment of flows as efficient as in manufacturing. The construction industry knows two typical problems resulting from high levels of fragmentation and low levels of repetition: lack of control and decreasing performance. Despite the critical role of a client, parties on the supply side - the lower tiers of the construction $\mathrm{SC}$ - are believed to be able to develop into more integrated systems, independently from the demand. Contractors are willing to develop closer relationships, but implementing SCM seems a long-term, complex process and requires a certain level of understanding and therefore learning throughout the supply chain. Some characteristics of the industry are even believed and described a non-suitable base for implementing SCM. This paper sets out to explore possibilities and examines the results of a step towards successful SCM in construction. It describes the advantages of the application of some important Lean principles, by presenting the differences within the processes needed to produce one construction 'product' in two different ways - with a product- and project-focus. The two cases involve a supply chain, operating in the Dutch construction industry and representing long-term agreements between one main contractor and its most critical suppliers in housing. With the analysis, the paper provides the reader with the necessary insights to take an important step in implementing SCM in construction.
\end{abstract}

Keywords: Supply chain Management, lean construction, lead time reduction, value stream thinking, flow.

\section{INTRODUCTION \& BACKGROUND}

Construction is a complex systems industry, managed through projects involving multiple, temporary, and transient organisations, complex contractual relationships and discontinuity of teams (Kumaraswamy et al., 2005; Pryke, 2012; Fulford \& Standing, 2014). The management of these discontinuous exchanges in project-based industries is problematic due to the discontinuity of demand for projects, the uniqueness of each project in technical, financial and socio-political terms, and the complexity of each project in terms of the number of actors involved (Skaates et al., 2002; Crepsin-Mazet \& Ghauri, 2007). The relationships required for the delivery of the constructed product among main contractors and suppliers are often weak and difficult to manage (King \& Pitt, 2009) and the low levels of repetition increase the unpredictability of the flow of work (Vrijhoef, 2011). The consequences are poor production processes, limited ability or willingness to innovate, late project delivery and budget overrun (Morledge et al., 2009).

Several studies have underlined the need for radically different approaches to supply chain relationships that achieve 'customer delight' and minimise turbulence in stakeholders' relationships (Latham, 1994; Cox \& Ireland, 2002; Pryke, 2009) and there has

SCM Consultant and part-time Research Student, The Bartlett School of Construction \& Project Management, University College London, London, UK, r.d.broft@gmail.com 
been a move towards better supply chain integration, and the formation of strategic partnerships and collaborative agreements between supply chain actors since (Akintoye et al., 2000; Holti et al., 2000; Briscoe \& Dainty, 2005).

At the lower tiers of the construction supply chain, the supply side, however, there remains a paucity of properly documented examples of successfully implemented Supply Chain Management (SCM) initiatives (Cox \& Ireland, 2002; Broft et al., 2016). Although fragmentation in construction originally occurred in response to highly variable workloads (Fulford \& Standing, 2014), main contractors now increasingly depend on their suppliers, both for realising projects and for achieving the required performance in these projects they require capabilities and knowledge which do not belong to their own core competences or in-house capabilities (Cox \& Ireland, 2002; Green at al., 2005; Mbachu, 2008; Bemelmans et al., 2012). The increasing percentage of project turnover which is spent on buying goods/services does provide opportunities for collaboration and emphases the importance of managing suppliers (Bemelmans et al., 2012). Contractors are willing to develop closer relationships (Ross \& Goulding, 2007), but implementing SCM seems a long-term, complex process and requires a certain level of understanding and therefore learning throughout the supply chain. Some characteristics of the industry are believed and described a non-suitable base for implementing SCM (Cox \& Ireland, 2006). This study sets out to explore possibilities and examines the results of a step taken towards 'successful' SCM at the lower tiers in construction.

\section{CONCEPTUAL DEVELOPMENT}

\subsection{The Construction Supply Chain}

In construction, a supply chain shows the following production-related characteristics:

- Converging logistics to a common and fixed point in the supply chain: the construction site where the 'construction factory' is located - the object is assembled from incoming materials, coming from different supply units, and through different services (Luhtala et al., 1994);

- Temporary and non-repetitive, or in other words, one-off construction projects that are produced through repeated reconfiguration of project organisations (Vrijhoef \& Koskela, 2000). This takes along difficulties to production standardisation and modularisation, and limits gains of scale (Gosling \& Naim, 2009). The organisations involved present high levels of autonomy;

- Multiple and concurrent projects, which produce significant implications at five categories: Capacity (balance the demand for accessing resources), complexity, conflict (unstable relationships), lack of commitment, and context.

- A number of studies have linked construction with the characteristics of the Engineer-to-order (ETO) production strategy (Segerstedt \& Olofsson 2010, Gosling et al., 2012). ETO-projects are described as having high levels of customisation and typically managed on a project basis (Gosling et al., 2012). Construction has generally an early Order penetration point (OPP).

- The choice of production process depends on process and product features. Construction is mainly based on two types of processes: small batch process and job process (Krajewski et al., 2007). 
These characteristics are often seen as peculiarities of the industry and prevent the attainment of flows as efficient as in manufacturing (Koskela, 1992). The high levels of alignment and repetition within these supply chains have led to highly productive and fast operating strategic coalitions of firms (Kirche et al., 2005; Kim, 2006). The construction industry on the contrary, knows two typical problems resulting from high levels of fragmentation and low levels of repetition: lack of control and decreasing performance. The main contractor, the principal construction organisation that manages a construction project, executes only a small part of the product by its own personnel and its own production facilities (Dubois \& Gadde, 2000).

\subsection{SCM in Construction}

SCM is a new way of thinking about management and processes, in order to coordinate supply chains more efficiently, by managing the associated relationships to deliver customer value, through innovation and continuous improvement (Christopher, 2005; Pryke, 2009; Blanchard, 2010; Fulford \& Standing, 2014). A supply chain is described as a network of interconnected - through upstream and downstream linkages - organisations that are involved in the different processes and activities that produce value in the form of products/services to the ultimate consumer (Harland, 1996; Dainty et al., 2001; Christopher, 2005). The main objective of SCM is to enhance mutual competitive advantage through improved relationships, integrated processes and increased customer focus (Pryke, 2009). Businesses no longer compete as a sole entity, but rather in a 'supply chain versus supply chain’ manner (Lambert \& Cooper, 2000; King \& Pitt, 2009).

Despite the critical role of a client in enabling supply chain integration, parties on the supply side - the lower tiers of the construction supply chain - are believed to be able to develop into more integrated production systems, independently from the demand (Vrijhoef \& De Ridder, 2005; Segerstedt \& Olofsson, 2010). Main contractors are acknowledged to have a central position in the management of supply chains (Pryke, 2009; Broft et al., 2016) - it is believed that main contractors have more influence on the organisation of the project and on the performance and quality of the work of its suppliers (Latham, 1994) - offering great potential in the effective integration of their supply chains. Implementation of SCM by main contractors, however, is relatively slow as SCM is often seen as a project-specific approach rather than a central strategy such as in industries like aerospace and car manufacturing (Green et al., 2005). Many applications have been limited to the management of construction materials and long-term arrangements with suppliers (Vrijhoef, 2011).

\subsection{A Lean Perspective to SCM in Construction}

The role of the supply system (or supply chain, network, stream, etc.) - comprising the purchasing activities of the assemblers and the supply activities of the component manufacturers (Lamming, 1996) - received attention from the outset of the discussion on Lean Production. Lean Production is the more generic and less culturally specific label for the Toyota Production System (TPS) - a de-contextualisation of a new dominant paradigm that is displacing mass production in search for methods to compress time and increase flow (Samuel et al., 2015). The logic of lean production describes value-adding processes unencumbered by waste, where lean is a means of waste identification in operations so that it can be eliminated for greater efficiency - to ensure that value flows swiftly and smoothly to the customer (Schniederjans et al., 2010; Samuel et al., 2015).

Lean challenges to fundamentally rethink value from the customer. This includes the identification of the 'entire' value stream (Womack \& Jones, 2003). The value stream is 
the set of all the specific actions required to bring a specific product/service through the critical management tasks of any business. Lean thinking must go beyond the firm to look at the whole: the entire set of activities entailed in creating and producing a specific product. Flow is created in order to accomplish tasks continuously from raw material to finished good rather than departmentalised, in batches (Womack \& Jones, 2003).

The project-focus within the 'project-based production system' known in construction, supporting fragmentation and the believed uniqueness of each project, seems to overrule this product-focus and the advantages of flow, necessary to improve customer value. In Lean SCM, the entire flow from raw materials to consumer is considered as an integrated whole (Lamming, 1996). Interfaces between the different companies of the supply chain are thus seen as artificial - as a result of the economic arrangement of assets governed by many other factors rather than as natural transformation stages in the development (or addition of value) (Lamming, 1996). The combination of lean applied to the management of supply chains can generate outstanding business performance. It involves the application of all the lean principles within a SCM context (Schniederjans et al., 2010). Some authors refer to this combination as supply chain best practices (Blanchard, 2010), a lean supply chain (Wincel, 2004), or a way of harnessing value in the supply chain (Banfield, 1999). Lean SCM could be defined as "the use of a highly transparent, trusting and long-term relationship between the buyer and supplier to create a physically efficient supply chain through the reduction of waste in processes or responsiveness in product delivery" (Schniederjans et al., 2010). Value creation, that has become a function of the network of iterative and transient relationships between actors, is central.

This paper describes the advantages of the application of some important Lean principles to SCM in construction, through the use of a case study.

\section{Research Methodology}

A main contractor has initiated the integration of its supply chain and decided to form long-term agreements with twelve suppliers in its key supply categories (Holti et al., 2000). For reasons of capacity and limited working areas, the main contractor selected more than one supplier for finishing and tiling services, and the production of frames.

The study, conducted in the Netherlands, involves case study research (Yin, 2014) case study research appears to be highly relevant to an industry that is project driven and made up of many different types of organisations, and comprises the following combination of data collection: Semi-structured interviews - where the emphasis is towards investigating a phenomenon within a context (Fellows \& Liu, 2003), and detached observation. For this research an experiment was proposed, where the supply chain was challenged to adapt a product-focus within a project, rather than the usual project-focus generally known in construction. This means that tasks were continuously, and directly after each other, performed from foundation to the delivery of one completed product flow of the product. The studied supply chain focuses on housing and the study was conducted on a project existing of 40 houses. Part of the project was constructed as Case I, the experiment, and the other part as Case II, the traditional situation - the activities of each supply chain actor are in flow (batch process). Due to chosen region, only nine suppliers were involved in the cases.

Data collection was largely based on primary data and gathered from semi-structured interviews with two key representatives - at management and project level - from each organisation involved. This approach is qualitative and investigates dependencies, barriers and points of improvement following from both cases. The study also uses detached 
observation of the processes needed to produce one construction 'product' in two different ways, based on the activities of the workers on site. Through the use of Multi Moment Analysis (MMA) on site, the study examines the differences in lead times of all activities, and the amount of value-adding activities performed - value/waste ratios were calculated after classification (Womack \& Jones, 2003).

The aim of the study is to investigate the effect value-stream thinking and flow, two important Lean principles, have on the collaboration within a supply chain and the SCM activities initiated by a main contractor. This way it provides readers with the necessary insights to take an important step towards the implementation of SCM in construction.

\section{RESEARCH FINDINGS}

It should be noted that the findings have limitations presented by the chosen research methodology, and concern only one supply chain and two cases within one project.

\subsection{A Comparison of two Cases}

The findings, resulting from the MMAs, give insight in the average duration, starting and finishing points of all activities performed on the construction 'product'. Table 1 gives a summarised and combined overview of these metrics per supply chain actor. It also shows the total number of employees needed to perform all discipline-dependent activities.

Table 1: A comparison of the two cases

\begin{tabular}{|c|c|c|c|c|c|c|c|c|c|}
\hline \multirow{2}{*}{$\begin{array}{l}\text { Supply } \\
\text { Chain } \\
\text { Actor }\end{array}$} & \multirow[t]{2}{*}{ Discipline } & \multicolumn{3}{|c|}{$\begin{array}{c}\text { Activities Case I } \\
\text { (Experiment) }\end{array}$} & \multicolumn{3}{|c|}{$\begin{array}{c}\text { Activities Case II } \\
\text { (Traditional) }\end{array}$} & \multirow{2}{*}{$\begin{array}{l}\text { Number of } \\
\text { employees } \\
\text { involved }\end{array}$} & \multirow[t]{2}{*}{$\begin{array}{c}\text { Value/waste } \\
\text { ratio }\end{array}$} \\
\hline & & $\begin{array}{l}\text { Lead } \\
\text { time }\end{array}$ & Start & End & $\begin{array}{l}\text { Lead } \\
\text { time }\end{array}$ & Start & End & & \\
\hline T00 & Main contracting & 20 days & 1 & 20 & 50 days & 1 & 50 & 2 & $12 / 88$ \\
\hline $\mathrm{T} 01$ & Production of foundations & 1 day & 1 & 1 & 1 day & 1 & 2 & 2 & $17 / 83$ \\
\hline T02 & Production of concrete & 3 days & 2 & 4 & 10 days & 3 & 13 & 5 & $13 / 87$ \\
\hline T03 & Production of roofing & 6 days & 4 & 9 & 17 days & 17 & 34 & 2 & $22 / 78$ \\
\hline T04 & Installation technology & 17 days & 1 & 17 & 48 days & 1 & 48 & 5 & $34 / 66$ \\
\hline T05 & Production of frames & 1 day & 18 & 18 & 1 day & 48 & 48 & 2 & $34 / 66$ \\
\hline T06 & Production of frames & & & & & & & & \\
\hline T07 & Finishing & 15 days & 2 & 16 & 22 days & 21 & 43 & 5 & $35 / 65$ \\
\hline T08 & Finishing & & & & & & & & \\
\hline T09 & Tiling & 7 days & 12 & 18 & 8 days & 36 & 44 & 4 & $15 / 85$ \\
\hline T10 & Tiling & & & & & & & & \\
\hline T11 & Production of doors & 1 day & 18 & 18 & 1 day & 48 & 49 & 2 & $39 / 61$ \\
\hline $\mathrm{T} 12$ & Contractor of storages & 11 days & 1 & 11 & 12 days & 38 & 50 & 5 & $21 / 79$ \\
\hline
\end{tabular}

The biggest difference between the two cases lies in the average total lead time needed to construct one product, one house. The findings show a lead time of 20 days in Case I, the experiment, and 50 days in Case II, the traditional situation. A difference caused by the way individual tasks were performed - continuous flow of the product versus batch production of all the tasks per discipline, or in other words the amount of time a product needs to wait for its next value-added activity.

Additionally, the table shows the average value/waste ratio per discipline after all activities were classified. The total ratio between value-adding and waste activities is $29 / 71$ (see Figure 1). The biggest types of waste can be appointed to motion of personnel $(18 \%)$ and waiting times (8\%) within the activities of different disciplines.

\subsection{The Key Representatives' perspectives}

The findings based on the semi-structured interviews reveal the different perspectives of key representatives (from every supply chain actor involved) about dependencies, barriers 
and points of improvement (based on types of waste found) during the performance of both cases. An overview of the findings is shown in Table 2 .

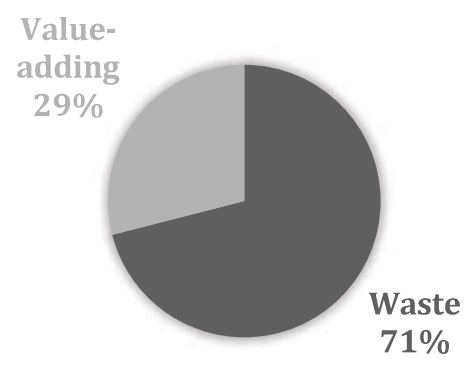

Figure 1: Total overview of value-added and waste activities.

Table 2: Overview of the dependencies, barriers and points of improvement.

\begin{tabular}{|c|c|c|c|c|}
\hline $\begin{array}{l}\text { Supply } \\
\text { Chain } \\
\text { Actor }\end{array}$ & Dependencies & Batch & Barriers & Biggest types of waste \\
\hline T00 & & - & Currently no employees on site. & Over-processing, motion \\
\hline T01 & T00, T02, T04 & 20/week & $\begin{array}{l}\text { Underload (transport), pile deviation, } \\
\text { alternation of tasks }\end{array}$ & Motion, waiting \\
\hline T02 & T00, T01 & 5-7/week & $\begin{array}{l}\text { Change in structure, safety, alternation } \\
\text { of tasks, lower production on site }\end{array}$ & Motion, waiting \\
\hline T03 & T00, T02, T04 & 6/week & $\begin{array}{l}\text { Limited day production, underload } \\
\text { (transport) }\end{array}$ & Waiting, transportation \\
\hline T04 & $\begin{array}{l}\text { T00, T01, T02, } \\
\text { T07, T09, T12 }\end{array}$ & $\begin{array}{l}\text { Differs per } \\
\text { discipline }\end{array}$ & $\begin{array}{l}\text { Great dependency, many different } \\
\text { disciplines/tasks performed on product }\end{array}$ & Over-processing, motion \\
\hline T05 & T07 & $6 /$ week & Risk of wrong fit with current system & Motion, transportation \\
\hline \multicolumn{5}{|c|}{ 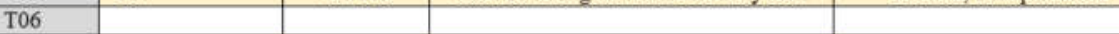 } \\
\hline T07 & T05 & $\begin{array}{l}\text { Differs per } \\
\text { discipline }\end{array}$ & $\begin{array}{l}\text { Limited day production, many different } \\
\text { disciplines/tasks performed on product }\end{array}$ & Motion, measurement \\
\hline \multicolumn{5}{|l|}{ T08 } \\
\hline T09 & T04, T07 & 5/week & $\begin{array}{l}\text { Limited day production, last-minute } \\
\text { changes in client options in relation to } \\
\text { production }\end{array}$ & Motion, measurement \\
\hline \multicolumn{5}{|c|}{ (a) } \\
\hline T11 & T00 & $5 /$ day & $\begin{array}{l}\text { Limited day production, alternation of } \\
\text { time tables }\end{array}$ & Motion, transportation \\
\hline $\mathrm{T} 12$ & T00, T01, T04 & $10 /$ day & Limited day production & Over-processing, waiting \\
\hline
\end{tabular}

During Case I, T01 proposed to help T02 with the installation of floors in order to decrease T02's activities to one day of production. Despite the fact that this task does not actually belong to its core business, its employees felt keen to think about who else to support in the future. T04, having specialised workers for every installation discipline, was challenged to overthink its task combinations. Interviewee T05 replies: "Collaboration between disciplines and people leads to many solutions - going for the same goal makes me willing to give". His employees found out about their dependency on the paint activities in the house. T03 has experienced that Case I invites workers to look beyond their own scope. The different answers show that site-workers discover unknown dependencies and feel more concerned than during Case II. Case II limits the scope of work to the employees' usual activities.

Interviewee T02, describes the construction method as the main challenge. His usual business challenge is to build as many structures as possible - mass production. Continuous flow asks for a different construction system, where his team activities and his transportation need to be adjusted. T03, also a production company, expects the traditional method, following Case II, to be more convenient for his type of company. T07 feels challenged in timing. Interviewee T09 describes this as "a puzzle and possibly a future 
barrier between projects to shift personnel and get to full day productions", whereas T04 sees this as challenges that could be overcome. According to some, mass production and batch thinking have more advantages than the continuous flow of a product - the interviews were held before insight of the results was provided.

\section{CONCLUSIONS}

The research findings outline important information about all the processes needed to produce one construction 'product'. The biggest difference is found in the delivery time, or in other words lead time, of this product -20 days versus 50 days in the traditional process - and relates to the flow within the activities of all individual organisations versus the continuous flow of activities on the product. Where the value/waste ratio within these activities remain rather the same - the two biggest types of waste can be appointed to motion of personnel and waiting times within the activities - a lot of extra waste can be defined as 'waiting' time of the product between the activities of all parties.

This research provides the supply chain with information on how to improve its processes - both as individual organisations and as a supply chain - and eliminate waste. Additionally, it shows differing dependence in the two cases between the activities needed to produce a construction 'product' and deliver it to the customer. In case of continuous flow (Case I), supply chain actors become a lot more dependent on each other and therefore, tend to support each other by helping and/or taking over activities outside their usual scope, beyond the boundaries of their organisation. Moreover, it creates a learning loop of correct implementation of all discoveries onto the next product.

This paper gives an example and the results of the combined application of lean principles to SCM, where a supply chain based on long-term collaboration, is trying to integrate their activities. This way, it provides readers with the necessary insights to take an important step in implementing SCM in construction.

\section{REFERENCES}

Akintoye, A., McIntosh, G. and Fitzgerald, E. (2000), "A survey of supply chain collaboration and management in the UK construction industry", European Journal of Purchasing \& Supply Management, Vol. 6, No. 3-4, pp. 159-168.

Bemelmans, J., Voordijk, H. and Vos, B. (2012), "Supplier-contractor collaboration in the construction industry: A taxonomic approach to the literature of the 2000-2009 decade", Engineering, Construction and Architectural Management, Vol. 19, No. 4, pp. 342-368.

Banfield, E. (1999), "Harnessing Value in the Supply Chain", John Wiley \& Sons, New York, NY.

Blanchard (2010), "Supply Chain Management: Best Practices", John Wiley \& Sons, Oxford.

Briscoe, G. and Dainty, A. (2005), "Construction supply chain integration: an elusive goal?”, Supply Chain Management: An International Journal, Vol. 10, No. 4, pp. 319326.

Broft, R.D., S. Badi and Pryke, S. (2016), "Towards SC Maturity in Construction", Built Environment Project and Asset Management, Emerald, Special Issue.

Cox, A. and Ireland, P. (2002), "Managing construction supply chains: the common sense approach", Engineering, Construction and Architectural Management, Vol. 9, No. 5/6, pp. 409-418. 
Cox, A. and Ireland, P. (2006), "Relationship management theories and tools in project procurement" in: Pryke, S.D. and Smyth, H.J. (Eds.) Management of Complex Projects: A relationship Approach, Blackwell, Oxford.

Christopher, M. (2005), "Logistics and Supply Chain Management: creating value-adding networks", Pearson Education, Harlow.

Dainty, A.R.J., Briscoe, G.H. and Millett, S.J. (2001), "New perspectives on construction supply chain integration", Supply Chain Management: An international Journal, Vol. 6, No. 4, pp. 163-173.

Dubois, A. and Gadde, L.E. (2000), "Supply strategy and network effects - purchasing behaviour in the construction industry", European Journal of Purchasing \& Supply Management, Vol. 6, No. 3-4, pp. 207-215.

Fulford, R. and Standing, C. (2014), "Construction industry productivity and the potential for collaborative practice", International Journal of Project Management, Vol. 32, No. 2, pp. 315-326.

Gosling, J., and Naim, M.M. (2009), "Engineer-to-order supply chain management: a literature review and research agenda", International Journal of Production, Economics, Vol. 122, No. 2, pp. 741-754.

Gosling, J., Towill, D.R., and Naim, M.M. (2012), "Learning how to eat an elephant: implementing supply chain management principles", Proceedings of the 28th Annual ARCOM Conference, 3-5 September, Edinburgh, UK.

Green, S.D., Fernie, S. and Weller, S. (2005), "Making sense of supply chain management: a comparative study of aerospace and construction", Construction Management and Economics, Vol. 23, No. 6, pp. 579-593.

Fellows, R. and Liu, A. (2003), "Research Methods for Construction", Blackwell Publishing, Oxford.

Harland, C.M. (1996), "Supply Chain Management: Relationships, Chains and Networks", British Journal of Management, Vol. 7, No. S1, pp. S63-S80.

Holti, R., Nicolini, D. and Smalley, M. (2000), "The handbook of supply chain management: the essentials", Construction Industry Research and Information Association and The Tavistock Institute, London.

Kim, S.W. (2006), "The effect of supply chain integration on the alignment between corporate competitive capability and supply chain operational capability", International Journal of Operations \& Production Management, Vol. 26, No. 10, pp. 1084-1107.

King, A.P. and Pitt, M.C. (2009), "Supply Chain Management: A Main Contractor's Perspective", in Pryke, S. (Ed.) Construction Supply Chain Management: Concepts and Case Studies, Wiley-Blackwell, Oxford, pp. 182-198.

Kirche, E.T., Kadipasaoglu, S.N. and Khumawala, B.M. (2005), "Maximizing supply chain profits with effective order management: integration of activity-based costing and theory of constraints with mixed-integer modelling", International Journal of Production Research, Vol. 43, No. 7, pp. 1297-1311.

Koskela, L. (1992), "Application of the New Production Philosophy to construction", CIFE Technical Report No. 72, Stanford Univeristy, Palo Alto, CA.

Krajewski, L. J., Malhotra, M. K., and Ritzman, L. P., (2015), "Operations Management: Processes and Supply Chains", Pearson.

Kumaraswamy, M.M., Ling, F.Y., Rahman, M.M. and Phng, S.T. (2005), "Constructing relationally integrated teams", Journal of Construction Engineering and Management, Vol. 131, No. 10, pp. 1076-1086. 
Lambert, D.M., Emmelhainz, M.A. and Gardner, J.T. (1996), "Developing and implementing supply chain partnerships", International Journal of Logistics Management, Vol. 7, No. 2, pp. 1-17.

Lamming, R. (1996), "Squaring lean supply with supply chain management", International Journal of Operations \& Production Management, Vol. 16, No. 2, pp. 183-196.

Latham, M. (1994), "Constructing the Team: Joint Review of Procurement and Contractual Arrangements in the UK Construction Industry: Final Report", HMSO, London.

Luhtala, M., Kilpinen, E., and Anttila, P. (1994), "LOGI Managing Make-to-Order Supply Chains", Report, Helsinki University of Technology, Finland.

Mbachu, J. (2008), "Conceptual framework for the assessment of subcontractors' eligibility and performance in the construction industry", Construction Management and Economics, Vol. 26, No. 5, pp. 471-484.

Morledge, R., Knight, A. and Grada, M. (2009), "The concept and development of supply chain management in the UK construction industry", in Pryke, S. (Ed.) Construction Supply Chain Management: Concepts and Case Studies, Wiley-Blackwell, Oxford, pp. 23-41.

Pryke, S. (2009), "Construction Supply Chain Management: Concepts and Case Studies", Wiley-Blackwell, Oxford.

Pryke, S. (2012), "Social Network Analysis in Construction", Wiley-Blackwell, Oxford.

Ross, A. and Goulding, J. (2007), "Supply Chain transactional barriers to design cost management", Construction Innovation, Vol. 7, No. 3, pp. 274-287.

Samuel, D., Found, P. and Williams, S.J. (2015), "How did the publication of the book The Machine That Changed The World change management thinking? Exploring 25 years of lean literature", International Journal of Operations \& Production Management, Vol. 35, No. 10, pp. 1386-1407.

Schniederjans, M. J., Schniederjans, D. G., and Schniederjans, A. M. (2010), "Topics in lean supply chain management". Singapore, World Scientific Publishing Company.

Segerstedt, A. and Olofsson, T. (2010), "Supply chains in the construction industry", Supply Chain Management: An International Journal, Vol. 15, No. 5, pp. 347-353.

Skaates, M.A., Tikkanen, H. and Lindblom, J. (2002), "Relationships and project marketing success", Journal of Business \& Industrial Marketing, Vol. 17, No. 5, pp. 389-406.

Vrijhoef, R. and Koskela, L. (2000), "The four roles of supply chain management in construction", European Journal of Purchasing \& Supply Management, 6, No. 3-4, pp. 169178.

Vrijhoef, R. and De Ridder, H.A.J. (2005), "Supply Chain Integration for achieving best value for construction clients: client-driven versus supplier driven".

Vrijhoef, R. (2011), "Supply Chain Integration in the building industry". Delft University Press.

Wincel, J.P. (2004), "Lean Supply Chain Management", Productivity Press, New York.

Womack, J. and Jones, D. (2003), "Lean Thinking", Simon and Schuster, NY.

Yin, R. (2014), "Case Study Research: Design and Methods" (5th ed.), Sage Publishing, Beverly Hills, CA. 